\title{
EFFECT OF DIFFERENT IRRIGATION SCHEDULING REGIEMS ON YIELD AND WATER CONSUMPTION OF SQUASH GROWN UNDER FIELD CONDITIONS
}

\author{
ZAYTON, A. M.
}

Agric. Eng. Res. Inst., ARC, Dokki, Giza, Egypt.

(Manuscript received 26 January 2015)

\begin{abstract}
$\mathrm{T}$ wo field experiments were carried out during the spring seasons of 2013 and 2014 at EL-Tahrir Provence, Behera Governorate, Egypt to study the effect of four different irrigation scheduling strategies on squash (cucurbita Pepo L.) yield and quality as well as water consumption under field conditions. Four scheduling irrigation treatments under drip irrigation system determining connected for evapotranspiration, accumulative evaporation, wetted area and the percentage of canopy cover these treatments were arrigned in randomized complete block design in three replications and designated as $A_{E T o r}, B_{E P}, C_{P_{W},}$ and $D_{P C}$, respectively. Results revealed that, the maximum seasonal applied irrigation water $\left(\mathrm{I}_{\mathrm{r}}\right)$ and water consumption $\left(\mathrm{E}_{\mathrm{t}}\right)$ of 547.2 , $398.36 \mathrm{~mm}$ and $562.0,409.15 \mathrm{~mm}$ were by $A_{\text {ETo }}$ treatment for the first and second season, respectively. While, $C_{\mathrm{Pw}}$ treatment recorded the minimum $I_{r}$ and $E_{t}$ values of $442.54,322.20 \mathrm{~mm}$ and $459.45,334.50 \mathrm{~mm}$ for the first and second season, respectively . Increasing $I_{r}$ resulting in increasing $E_{t}$ and significantly affecting the total yield and all vegetative traits as well as irrigation water use efficiency (IWUE). $A_{E T O}, D_{P C}$. and $B_{E P}$ treatments had the highest early and mean fruit yield of $1.35,1.28$, and $1.17 \mathrm{Mg} /$ Fed. and $12.0,10.62,10.0 \mathrm{Mg} / \mathrm{Fed}$. for the first season, respectively. Results of the second season regarding early and mean fruit yield had the same trend. Concerning the vegetative and quality traits, $A_{E T o r} D_{P C}$ and $B_{E P}$ treatments exhibited the maximum values regarding to fruit number and weight per plant, mean fruit weight, diameter and length. Meanwhile, $C_{\mathrm{Pw}}$ treatment had the lowest values which may be due to superior irrigation in early growth stage and insufficient water in the late growth stages which adversely affected the pant development and caused flowers shedding. $A_{E T}$ and $D_{P C}$. treatments had the highest IWUE values of 5.22 and $5.07 \mathrm{~kg} / \mathrm{m}^{3}$ for the first season and 5.13 and $4.92 \mathrm{~kg} / \mathrm{m}^{3}$ for the second season, respectively. As a conclusion, Irrigation scheduling based on the percentage of the canopy cover could be used as an alternative to using crop coefficient $\left(K_{c}\right)$ values especially, when $k_{c}$ values not available or not correctly defined. Meanwhile, Irrigation scheduling based on the percentage of wetted area $\left(P_{w}\right)$ seems to be not realistic or sensible, because using a fixed $P_{w}$ value was not appropriate for all plant growth stages.
\end{abstract}

Keywords: Squash, irrigation scheduling, evapotranspiration, wetted area, canopy cover and water consumption. 


\section{INTRODUCTION}

Competition among the limited water resources could escalate and Egypt could face an explosive situation due to the large and tightly packed population (EIRaey, 1999 and Abou Zeid, 2002). Sanchez, et al. (2005) stated that the water gap in Egypt will increase to reach 21.0 billon $\mathrm{m}^{3}$ by the year 2025.Efficient use of irrigation water in any irrigation system is becoming important particularly in arid and semiarid regions where water is a scarce commodity.Irrigation scheduling addresses how much and when to irrigate to achieve maximum water use efficiency. Water use efficiency in this context is generally understood to mean maximizing the amount of marketable crop produced per unit of water. Norwood and Dumler (2002) stated that use of proper irrigation management could increase water use efficiency; improve agricultural water consumption and subsequent use of that water for greater crop production. Potential evapotranspiration $\left(E T_{0}\right)$ is one of the important key factors used in determining crop water requirements and is essential criteria for on- farm irrigation management. It should be known to design irrigation supply system that can meet those requirements. One of the most debated issues in irrigation science is estimating $\mathrm{ET}_{\mathrm{O}}$ using weather data (Doorenbose and Pruit, 1977). Smith et al., (1996) recommended the use of FAO -Penman formula to calculate crop -water requirement, especially under limited climate data conditions. Gavilan and Castilo (2009) stated that accurate estimation of $\left(E T_{0}\right)$ in irrigated land is necessary for improving the planning and efficient use of water resources in semiarid regions. The most frequently used method for computing consumptive use of water by irrigated crop (crop evapotranspiration, $\mathrm{ET}_{\mathrm{C}}$ ) is a two-step approach that quantifies the atmospheric demand through the calculation of the reference evapotranspiration (ETO) and characterizes the crop growth through a crop coefficient $\left(\mathrm{K}_{\mathrm{C}}\right)$. The product of these two parameters provides an estimation of the crop evapotranspiration $\left(E T_{C}\right)$. Alternative approach for estimating ( $\mathrm{ET}_{\mathrm{O}}$ ) and consequently arrangement of irrigation programs is the class A- pan evaporimeter (Elliades, 1988). Class A- Pan evaporimeters are used because of their simplicity, low cost and proven ease of application in determining crop water requirements for irrigation scheduling (Stanhill, 2002). Nevertheless, Class A- pan must be maintained on a regular basis by renewing the water in the pan to avoid turbidity and should be kept free of algae or other organic growth because of their effect on evaporation rates. Pan must also be kept fenced to prevent animals' from drinking from them. Hartz (1993) mentioned that, as for irrigation scheduling an alternative to using published crop coefficient $\left(K_{c}\right)$ values is to develop coefficients based on the percentage of the soil surface covered by foliage, 
which Associated directly to the site -specific field configuration and plant vigor. The percentage of canopy cover $\left(P_{c}\right)$ is estimated by measuring the average in row plant width and dividing by the bed width. This approach works reasonably well for most ground grown vegetable crops; however,this system is less appropriate where crops are staked or trellised. Phene et al. (1985) mentioned that, peak crop water demand may slightly exceed potential evapotranspiration $\left(E T_{0}\right)$ therefore, the percentage of canopy cover should be estimated liberally. On the other side, Cetin and Bilgel (2002) used the percentage of canopy cover $\left(P_{c}\right)$ as an appropriate and reasonable way for calculation of amount of irrigation water for drip irrigated cotton.Drip Irrigation is one of the best techniques to use in applying water to vegetables and orchards. In the design of a drip irrigation system for improving water use and optimizing crop production , factors to be considered include plant spacing and plant canopy cover as well as soil texture, potential evaporation, water quality and topography. For these reasons, drip irrigation systems must be carefully designed and installed so that they operate with proper efficiency, and so that fertilizers and chemical can be applied in uniform and efficient manner. One of the most important advantages of drip irrigation is that it does not irrigate the whole surface of soil. Indeed, irrigation scheduling can be based on the degree to which the surface soil is wetted, with irrigation being controlled to keep the percentage wetter area within an upper and lower limit. The percentage of wetted area, $\mathrm{P}_{\mathrm{w}}$ is defined as the average horizontal area wetted in the top $15-30 \mathrm{~cm}$ of the crop root zone as a percentage of the total crop area. No accurate or proper minimum value for $\mathrm{P}_{\mathrm{w}}$ has been established. A reasonable objective for widely spaced crops is to wet as much as two-thirds of the potential horizontal cross- sectional area of the root system, 33\% $<\mathrm{P}_{\mathrm{w}}<67 \%$. Keller and Bliesner (1990) reported that, in regions that receive considerable supplemental rainfall, values lower than one third is acceptable for medium and heavy textured soils. However, in closely spaced crops with rows and emitter laterals spaced less than $1.8 \mathrm{~m}$ apart, $\mathrm{P}_{\mathrm{w}}$ often approaches $100 \%$.For a given value of $\mathrm{P}_{\mathrm{w}}$, different crop -soil -climate systems may show significant variations in performance. For that reason, to determine and use an appropriate percentage of the wetted area is important in terms booth of the system design and water use efficiency. Squash (CucurbitaPepo L.) considered as one of the most important cash crops, especially, in newly reclaimed areas of Egypt. Squash plants grow best on fertile, well-drained soil with organic matter in spring, summer and fall seasons. Mario et al., (1997) reported that squash is sensitive to, and my be damaged by excessive soil water from seed sowing to emergence, they added that, science squash rooting depth is relatively shallow, in the top of $40-50 \mathrm{~cm}$ of soil, soil water has to be maintained above $50 \%$ of the available soil capacity in order to avoid 
detrimental water deficit.El- Gindy et al. (2009) mentioned that subsurface drip irrigation method with $80 \% \mathrm{E}_{\mathrm{t}}$ crop and fertigation method are the best conditions for production the highest squash yield of $8.9 \mathrm{Mg} / \mathrm{fed}$. at El Boston area at Nubaria sector. They found that the maximum WUE value of $4.51 \mathrm{~kg} / \mathrm{m}^{3}$ was with $60 \%$ of the $E_{t}$ crop. Richard et al., (2002) stated that irrigation should be scheduled to avoid excessive moisture or water stress. Lake of adequate soil water at harvest can result in misshapen fruit, on the other side too much soil water can aggravate root and stem rot diseases. There is an urgent need to identify and adopt effective irrigation management strategies that allows growers to sustain profitable yield while it can greatly save irrigation water and reduce the potential chemical substances leaching in the soil.

Therefore, the main objective of this study was to identify suitable irrigation scheduling strategy to gain optimum squash yield and sustain irrigation water.

\section{MATERIALS AND METHODS}

\section{Experimental site:}

Two field experiments were carried out during the spring seasons of 2013 and 2014 at EL- Tahrir Provence, Behera Governorate, Egypt in a commercial grower's field, $30^{\circ} 65^{\circ} \mathrm{N}$; longitude $30^{\circ} 7^{\circ} \mathrm{E}$ and $16 \mathrm{~m}$ above the sea level, to study the effect of different irrigation management practices on squash (cucurbitaPepo L.) yield and quality as well as water consumptive use under field conditions. Soil samples were collected to a depth of $90 \mathrm{~cm}$ to determine its physical and chemical properties. Obtained results are presented in Table (1) and (2).

Table 1. Some physical properties of the experimental site.

\begin{tabular}{|c|c|c|c|c|c|c|c|c|c|}
\hline \multirow{2}{*}{$\begin{array}{c}\text { Soil depth } \\
(\mathrm{cm})\end{array}$} & \multicolumn{2}{|c|}{ Mechanical analysis } & & & & & \\
\cline { 2 - 8 } & Sand & Silt & Clay & $\begin{array}{c}\text { Texture } \\
\text { class } \\
(\%)\end{array}$ & $\begin{array}{c}\text { FC } \\
(\%)\end{array}$ & $\begin{array}{c}\text { WP } \\
(\%)\end{array}$ & $\begin{array}{c}\text { ASM } \\
(\%)\end{array}$ & $\begin{array}{c}\text { BD } \\
\mathrm{g} / \mathrm{cm}^{3}\end{array}$ & $\begin{array}{c}\mathrm{K}_{\mathrm{s}} \\
(\mathrm{mm} / \mathrm{h})\end{array}$ \\
\hline $0-30$ & 93.2 & 3.2 & 3.6 & Sandy & 11.6 & 6.1 & 5.5 & 1.58 & 72 \\
\hline $30-60$ & 92.1 & 4.1 & 3.8 & Sandy & 11.9 & 5.8 & 6.1 & 1.63 & 70 \\
\hline $60-90$ & 92.0 & 4.3 & 3.7 & Sandy & 10.8 & 4.9 & 5.9 & 1.65 & 73 \\
\hline
\end{tabular}


Table 2. Some chemical properties of the experimental site.

\begin{tabular}{|c|c|c|c|c|c|c|c|c|c|}
\hline \multirow{2}{*}{$\begin{array}{c}\text { Soil } \\
\text { depth } \\
(\mathrm{cm})\end{array}$} & \multirow{2}{*}{$\begin{array}{c}\mathrm{EC} \\
(\mathrm{dS} / \mathrm{m}) \\
\end{array}$} & \multirow[t]{2}{*}{$\mathrm{pH}$} & \multicolumn{4}{|c|}{$\begin{array}{c}\text { Soluble cations } \\
(\mathrm{meq} / \mathrm{l})\end{array}$} & \multicolumn{3}{|c|}{$\begin{array}{c}\text { Soluble anions } \\
\text { (meq/l) }\end{array}$} \\
\hline & & & $\mathrm{Ca}^{+2}$ & $\mathrm{Mg}^{+2}$ & $\mathrm{Na}^{+}$ & $\mathrm{K}^{+}$ & $\mathrm{HCO}_{3}^{-}$ & $\mathrm{SO}_{4}^{-2}$ & $\mathrm{Cl}^{-}$ \\
\hline $0-30$ & 1.35 & 7.55 & 1.35 & 0.68 & 1.85 & 0.35 & 1.55 & 0.82 & 1.85 \\
\hline $30-60$ & 1.26 & 7.50 & 1.22 & 0.66 & 1.65 & 0.35 & 1.39 & 0.75 & 1.74 \\
\hline $60-90$ & 1.10 & 7.70 & 1.18 & 0.65 & 1.72 & 0.18 & 1.36 & 0.73 & 1.64 \\
\hline
\end{tabular}

\section{Crop management:}

Squash seeds were sown on 15 and 18 March, respectively in rows $40 \mathrm{~m}$ length, $0.5 \mathrm{~m}$ width and about $0.5 \mathrm{~m}$ spacing between plants within rows. The experiments were terminated on 20 and 25 June for the first and second season, respectively.Plants were irrigated up field capacity after sowing to encourage germination and insure good plant establishment. Subsequent Irrigation events were every other day and based on the different irrigation scheduling strategies.

\section{Irrigation system:}

Drip irrigation system used in this experiment consists of PVCmain and submain lines with outer diameter of $110 / 90$ and $75 / 63 \mathrm{~mm}$ respectively. The manifolds were PE pipes with $32 \mathrm{~mm}$ outer diameter. Drip laterals $16 \mathrm{~mm}$ PE $0.5 \mathrm{~m}$ apart between the plant rows. Built-in emitters with $3.2 \mathrm{l} / \mathrm{h}$ flow rate at operating pressure of $100 \mathrm{kPa}$ were spaced $0.50 \mathrm{~m}$ in the lateral lines. The control head is located at the source of the water supply consists of centrifugal pump with $20 \mathrm{~m}^{3} / \mathrm{h}$ discharge at operating pressure of $400 \mathrm{kPa}$, media filter of 100 mesh followed by screen filter of 120 mesh, pressure gauges, pressure regulator, fertilizer tank and flow meter. Irrigation water was obtained from an open channel irrigation system in the experimental area and classified by $\mathrm{PH}$ value of 7.4 and average electrical conductivity (EC $C_{\text {iw }}$ ) of $1.45 \mathrm{dS} / \mathrm{m}$.

\section{Irrigation scheduling strategies:}

Four irrigationscheduling treatments were assigned in randomized complete block design in three replications and designated as $A_{E T O}, B_{E P}, C_{P W}$ and $D_{P C}$. $A_{E T O}$ :Irrigation scheduling based on potential evapotranspiration ( $\left.E T_{0}\right)$ :

The potential evapotranspiration ( $E T_{0}$ ) was calculated on a daily basis ( $\mathrm{mm} / \mathrm{day}$ ) by meansof penman- Monteith's formula using the CROPWAT computer program (smith et al., 1996). Necessary metrological data used for these calculations are provided by the Central laboratory for Agricultural Climate (CALC) of Egypt. Table (3) summarized the monthly mean climate data for the Tahrir province during the two growing seasons. Crop evapotranspiration $\left(\mathrm{ET}_{\mathrm{C}}\right.$ ) was based on the product of $\mathrm{ET}_{\mathrm{O}}$ and crop coefficient $K_{C}$ for a given growth stage as follows:

$$
\mathrm{ET}_{\mathrm{C}=} \mathrm{K}_{\mathrm{C}} \times \mathrm{ET}_{\mathrm{O}}
$$


Squash is about 100 days duration crop and may divided into four growth stages, namely initial, 20days; development, 30dayes; middle, 30days and late season, 20days. The crop coefficient values during the growing season as illustrated in Table (4) were $0.45,0.65,0.94$ and 0.73 at initial, development, middle, and late stages, respectively (Allen, et al., 1998).

Table 3. Monthly mean climatic data of the experimental site during 2013 and 2014 growing seasons.

\begin{tabular}{|c|c|c|c|c|c|c|c|c|}
\hline & \multicolumn{2}{|c|}{ March } & \multicolumn{2}{c|}{ April } & \multicolumn{3}{c|}{ May } & \multicolumn{2}{c|}{ June } \\
\cline { 2 - 9 } Variables & 2013 & 2014 & 2013 & 2014 & 2013 & 2014 & 2013 & 2014 \\
\hline $\mathrm{T}_{\max }\left({ }^{\circ} \mathrm{C}\right)$ & 22.8 & 23.2 & 25.85 & 26.30 & 31.1 & 30.8 & 33.15 & 33.6 \\
\hline $\left.\mathrm{T}_{\min }{ }^{\circ} \mathrm{C}\right)$ & 10.1 & 10.1 & 12.6 & 12.1 & 14.95 & 15.3 & 18.63 & 19.1 \\
\hline $\left.\mathrm{T}_{\text {avg }}{ }^{\circ} \mathrm{C}\right)$ & 16.4 & 16.6 & 19.22 & 19.2 & 23.0 & 23.0 & 25.72 & 26.3 \\
\hline $\mathrm{RH}(\%)$ & 59 & 60 & 55 & 55 & 56 & 55 & 57 & 56 \\
\hline $\mathrm{U}_{2}\left(\mathrm{~ms}{ }^{-1}\right)$ & 1.95 & 2.2 & 1.8 & 2.1 & 1.8 & 1.84 & 1.65 & 1.73 \\
\hline $\mathrm{R}_{\mathrm{s}}\left(\mathrm{Mjm}{ }^{-2} \mathrm{~d}^{-1}\right)$ & 18.1 & 18.3 & 21.4 & 21.4 & 25.75 & 25.8 & 28.9 & 28.5 \\
\hline $\mathrm{S}_{\mathrm{sh}}(\mathrm{hr})$ & 9.65 & 9.7 & 10.62 & 10.5 & 12.83 & 12.8 & 13.4 & 13.3 \\
\hline $\mathrm{R}(\mathrm{mm})$ & 9.5 & 8.3 & 5.3 & 5.6 & 0.33 & 0.45 & 0.0 & 0.10 \\
\hline $\mathrm{ET}_{\mathrm{O}}(\mathrm{mm} / \mathrm{day})$ & 3.63 & 3.86 & 4.62 & 4.73 & 5.85 & 5.7 & 6.85 & 7.12 \\
\hline $\mathrm{E}_{\mathrm{pan}}(\mathrm{mm} / \mathrm{day})$ & 4.78 & 4.93 & 6.32 & 6.45 & 7.55 & 7.85 & 8.50 & 8.85 \\
\hline
\end{tabular}

$\mathrm{T}_{\text {max },} T_{\text {min }}$ and $\mathrm{T}_{\text {avg }}$ are maximum, minimum and average air temperature; $\mathrm{RH}$ is the average air relative humidity; $U_{2}$ is the average wind speed; $R_{s}$ is theglobal solar radiation; $\mathrm{S}_{\mathrm{sh}}$ is the sunshine duration; $\mathrm{R}$ is the rainfall, $E T_{0}$ is the potential evapotranspiration and $E_{\text {pan }}$ is the average A-pan evaporation.

$\mathrm{B}_{\mathrm{Ep}}$ :Irrigation scheduling based on class A- Pan Evaporation $\left(\mathrm{ET}_{\mathrm{p}}\right)$ :

Evaporation between the irrigation intervals was measured using standard USWB- class A- Pan located at the experimental site. Daily water level changes were measured in $\mathrm{mm}$ throughout the growing season.

Crop water consumptive use $\left(E T_{C}\right)$ or evapotranspiration was estimated using the following form of the water balance equation according to Allen et al. (1998).

$$
\mathrm{ET}_{\mathrm{c}}=\mathrm{I}+\mathrm{P} \pm \Delta \mathrm{SW}-\mathrm{DP}-\mathrm{RO}
$$

Where $E T_{\mathrm{C}}$ is the evapotranspiration $(\mathrm{mm}), \mathrm{I}$ is the irrigation water $(\mathrm{mm}), \mathrm{P}$ is the precipitation $(\mathrm{mm}), \Delta S W$ is the change in the soil water storage $(\mathrm{mm})$ in the $90 \mathrm{~cm}$ soil depth, DP is the deep percolation ( $\mathrm{mm})$, and RO is the amount of runoff $(\mathrm{mm})$. Since the amount of irrigation water was controlled, the rainfall during the growing 
season was considered to be negligible, runoff was assumed to be zero; deep percolation below $90 \mathrm{~cm}$ soil depth was negligible. Therefore, one dimensional water balance equation can be used for estimation crop water consumptive use as follows:

$$
\mathrm{I}=\mathrm{A} \mathrm{E} p \quad \mathrm{~K} p \quad K_{C}
$$

Where I is the amount of irrigation water $\left(\mathrm{m}^{3}\right), A$ is the plot area $\left(\mathrm{m}^{2}\right), E_{p}$ is the amount of cumulative evaporation during an irrigation interval $(\mathrm{mm}), \mathrm{K}_{\mathrm{p}}$ is the coefficient of pan evaporation and $\mathrm{K}_{\mathrm{C}}$ is the crop coefficient.

$\mathrm{C}_{\mathrm{Pw}}$ : Irrigation scheduling based on the percentage of wetted area $\left(\mathrm{P}_{\mathrm{w}}\right)$ :

The percentage of wetted area was determined by methods from Keller and Bliesner (1990) using the following equation:

$$
\mathrm{P}_{\mathrm{w}}=\frac{\mathrm{E} * \mathrm{~S}_{\mathrm{e}} * \mathrm{~S}_{\mathrm{w}}}{\mathrm{S}_{\mathrm{p}} * \mathrm{~S}_{\mathrm{r}}} * 100
$$

Where, $P_{w}$ is the average horizontal area wetted in the top $15-30 \mathrm{~cm}$ of the crop root zone as a percentage of the each lateral line area; $E$ is the number of emission point per plant; $\mathrm{S}_{\mathrm{e}}$ spacing between emitters on the lateral line in $\mathrm{cm}$; $\mathrm{S}_{\mathrm{w}}$ is the diameter would be wetted by emitters in $\mathrm{cm} ; \mathrm{S}_{\mathrm{p}}$ is the plant spacing in the row in $\mathrm{cm}$ and $\mathrm{S}_{\mathrm{r}}$ is the row spacing in $\mathrm{cm}$. For a given value of $\mathrm{P}_{\mathrm{w}}$, different crop - soil- climate systems may show significant variations in performance. Therefore, determine and use an appropriate percentage of the wetted area is important in terms both of the system design and water use efficiency. According to Black (1971), the recommended values of the percentage of wetted soil area are up around $50 \%$ quite satisfactory and should be more than $35 \%$ in arid and semi-arid regions. No single "right" or "proper" minimum $\mathrm{P}_{\mathrm{w}}$ value has been established. In this study the percentage of wetted area was set to a value of $46 \%$ throughout the growing season based on the laterals spacing and plant geometry.

$D_{P c}$ :Irrigation scheduling based on the percentage of canopy cover $\left(P_{c}\right)$ :

The percentage of canopy cover $\left(P_{c}\right)$ was determinedaccording to Hartz (1993)by measuring the average in-row plant width (i.e. shaded width) and dividing by the bed width (i.e. row space). Pc was determined before each irrigationcycle, and used for calculation the amount of irrigation water applied. The percentage of canopy cover was set at 30\% from planting until the canopy cover exceeded $30 \%$ after which it was then set to the measured values until the last irrigation event for both growing seasons. The following equation can be utilized for estimation water consumptive use for treatments $C$ and $D$ as follows:

$$
\mathrm{I}=\mathrm{A} \text { Ep Kp P }
$$

Where $\mathrm{P}$ is the percentage of wetted area $\left(\mathrm{P}_{\mathrm{w}}\right)$ or the percentage of canopy cover $\left(\mathrm{p}_{\mathrm{c}}\right)$. 


\section{Squash vegetative traits, yield and quality parameters:}

Squash fruits were first harvested 60days after sowingby hand harvesting and there were about 15 harvest events during the rest of the two growing seasons depending on harvest maturity of plants. The harvest area in each plot was $7.5 \mathrm{~m}^{2}$ (the $5 \mathrm{~m}$ section of the three adjacent center rows in each plot). Early fruit yield, mean fruit yield, fruit number per plant, mean fruit weight, fruit weight per plant and mean fruit length and diameter were measured or determined.

\section{Irrigation Water use Efficiency (IWUE):}

Irrigation Water use Efficiency (IWUE) is generally defined as crop yield per water used to produce the yield (Howell, 2006). Thus, IWUE was calculated as the total marketable yield, $E_{\mathrm{y}}(\mathrm{kg})$ obtained per unit volume of irrigation water applied, $\mathrm{I}_{\mathrm{r}}\left(\mathrm{m}^{3}\right)$ as follows:

$$
\operatorname{IWUE}=\frac{E_{\mathrm{y}}}{I_{\mathrm{r}}}
$$

\section{Statistical analysis:}

Statistical analysis of the data was performed using a randomized complete block design with three replicates. The statistical Package (CoHort, 1986) was used for data analysis. The treatments were run as a single-factor analysis of variances (ANOVA). The probability level for determination of significance was 0.05 .

\section{RESULTS AND DISCUSSION}

\section{Applied irrigation water $\left(I_{r}\right)$ and plant water consumption $\left(E_{t}\right)$ :}

To encourage the germination and insure plant establishment, all treatments were irrigated up field capacity after sowing. Then, scheduled irrigation was initiated every second daybased on the different scheduling strategies. The potential evapotranspiration $\left(E T_{O}\right.$ ) values were 539.25 and $556 \mathrm{~mm}$ for the first and second growing season, respectively. Meanwhile, the cumulative evaporation $\left(E_{\text {Pan }}\right)$ values ranged from 700.45 to $727.15 \mathrm{~mm}$ for 2013 and 2014 growing seasons, respectively as shown in Table (4). $A_{\text {Eтo }}$ treatment had the highest $I_{r}$ and $E_{t}$ values of 547.2, 562 $\mathrm{mm}$ and 398.36, $409.13 \mathrm{~mm}$ for the first and second season, respectively. While, $\mathrm{C}_{\mathrm{PW}}$ treatment had the lowest $I_{r}$ and $E_{t}$ values of $442.54,459.45 \mathrm{~mm}$ and $322.2,334.50$ $\mathrm{mm}$ for the first and second season, respectively as presented in Table (5). On the other hand $\mathrm{C}_{\mathrm{PW}}$ treatment consumed more irrigation water than the other treatments during the initial growth stage and this-performance means that fixed wetted percentage value may not proper for all growth stages. There was a significant positive correlation between the amount of applied irrigation water and plant water consumption. Also, it was noticed that, the plant water consumption increased towards the end of the growing season as the weather parameter increased. Similarly, 
plant water consumption increased with increasing the amount of applied irrigation water as shown in Table (5) and Fig. (1).

Table 4. Growth stages periods, crop coefficient for squash, the percentage of wetted area and canopy cover, accumulative A-Pan and potential evapotranspiration values.

\begin{tabular}{|c|c|c|c|c|c|c|c|}
\hline \multicolumn{2}{|r|}{ Growth stages } & $\begin{array}{l}\text { Duration } \\
\text { (days) }\end{array}$ & $\mathrm{K}_{\mathrm{c}}$ & $\begin{array}{l}\mathrm{P}_{w} \\
(\%)\end{array}$ & $\begin{array}{l}P_{c} \\
(\%)\end{array}$ & $\mathrm{E}_{\mathrm{pan}}(\mathrm{mm})$ & $\begin{array}{l}\mathrm{ET}_{0} \\
(\mathrm{~mm})\end{array}$ \\
\hline \multirow{4}{*}{$1^{\text {st }}$} & $\begin{array}{l}\text { Initial stage, } \\
15 \text { Mar.-3 Apr. }\end{array}$ & 20days & 0.45 & 46 & 30 & 100.25 & 75.60 \\
\hline & $\begin{array}{c}\text { Crop development stage, } 4 \\
\text { Apr.-3 May. }\end{array}$ & 30 days & 0.65 & 46 & 75 & 193.30 & 142.30 \\
\hline & $\begin{array}{l}\text { Mid- season stage, } \\
4 \text { May.-2 Jun. }\end{array}$ & 30 days & 0.94 & 46 & 87 & 228.40 & 177.50 \\
\hline & $\begin{array}{l}\text { Late- season stage, } \\
3 \text { Jun.-23 Jun. }\end{array}$ & 21 days & 0.73 & 46 & 81 & 178.50 & 143.85 \\
\hline \multirow{5}{*}{$2^{\text {ed }}$} & Total & 101 days & & & & 700.45 & 539.25 \\
\hline & $\begin{array}{l}\text { Initial stage, } \\
18 \text { Mar. }-6 \text { Apr. }\end{array}$ & 20days & 0.45 & 46 & 30 & 107.75 & 82.50 \\
\hline & $\begin{array}{c}\text { Crop development stage, } 7 \\
\text { Apr.-6 May. }\end{array}$ & 30 days & 0.65 & 46 & 77 & 201.90 & 148.70 \\
\hline & $\begin{array}{l}\text { Mid- season stage, } \\
7 \text { May. }-5 \text { Jun. }\end{array}$ & 30 days & 0.94 & 46 & 90 & 240.50 & 182.40 \\
\hline & $\begin{array}{l}\text { Late- season stage, } \\
6 \text { Jun.-25 Jun. }\end{array}$ & 20 days & 0.73 & 46 & 83 & 177.00 & 142.40 \\
\hline & Total & 100 days & & & & 727.15 & 556.00 \\
\hline
\end{tabular}

Table 5. plant water consumption (Et) and Applied irrigation water (Ir).

\begin{tabular}{|c|c|c|c|c|c|c|c|c|}
\hline \multirow{3}{*}{ Growth stages } & \multicolumn{8}{|c|}{ Treatments } \\
\hline & \multicolumn{2}{|c|}{$\begin{array}{c}A_{\text {EтO }} \\
(\mathrm{mm})\end{array}$} & \multicolumn{2}{|c|}{$\begin{array}{c}\mathrm{B}_{\mathrm{Ep}} \\
(\mathrm{mm})\end{array}$} & \multicolumn{2}{|c|}{$\begin{array}{c}\mathrm{C}_{\mathrm{Pw}} \\
(\mathrm{mm})\end{array}$} & \multicolumn{2}{|c|}{$\begin{array}{c}D_{\mathrm{Pc}} \\
(\mathrm{mm})\end{array}$} \\
\hline & $E_{t}$ & $\mathrm{I}_{\mathrm{r}}$ & $E_{t}$ & $I_{r}$ & $E_{t}$ & $I_{r}$ & $E_{t}$ & $I_{r}$ \\
\hline Initial & 34.01 & 46.72 & 31.57 & 43.36 & 46.10 & 63.32 & 21.05 & 28.92 \\
\hline Development & 92.49 & 127.04 & 87.95 & 120.81 & 88.91 & 122.11 & 101.48 & 139.40 \\
\hline Mid- season & 166.85 & 229.19 & 150.27 & 206.44 & 105.07 & 144.32 & 139.10 & 191.06 \\
\hline Late- season & 105.01 & 144.25 & 91.21 & 125.29 & 82.12 & 112.79 & 101.21 & 139.02 \\
\hline $\begin{array}{c}\text { Total, } 1^{\text {st }} \\
\text { season } \\
\end{array}$ & 398.36 & 547.20 & 361.00 & 495.90 & 322.20 & 442.54 & 362.84 & 498.40 \\
\hline Initial & 37.09 & 50.95 & 33.94 & 46.61 & 49.55 & 68.06 & 22.63 & 31.08 \\
\hline Development & 96.70 & 132.8 & 91.86 & 126.19 & 92.87 & 127.58 & 108.82 & 149.28 \\
\hline Mid- season & 171.41 & 235.45 & 158.25 & 217.36 & 110.65 & 151.96 & 151.51 & 208.13 \\
\hline Late- season & 103.95 & 142.80 & 90.45 & 124.24 & 81.43 & 111.85 & 102.84 & 141.26 \\
\hline $\begin{array}{c}\text { Total, } 2^{\text {ed }} \\
\text { season }\end{array}$ & 409.15 & 562.00 & 374.50 & 514.40 & 334.50 & 459.45 & 385.80 & 529.75 \\
\hline
\end{tabular}




\section{Yields and vegetative growth traits:}

Yields and vegetative growth traits data of squash plant as affected by different irrigation scheduling strategies for the two growing seasons are presented in Tables (6 and 7). Squash fruits were first harvested 60days after sowing and there were about 15 harvest events during the rest of the two growing seasons.
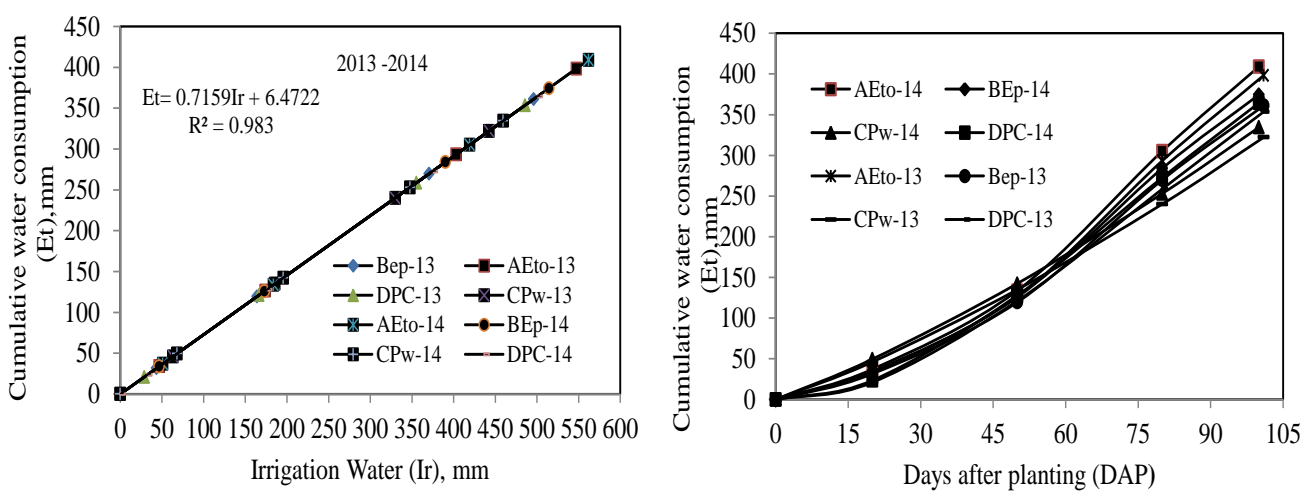

Fig. 1. Cumulative water consumption throughout the two growing seasons and applied irrigation water.

Table 6. Early and mean fruit Yield, fruit number per plant and mean fruit weight of squash plant as affected by different irrigation scheduling strategies.

\begin{tabular}{|c|c|c|c|c|c|}
\hline \multirow[b]{2}{*}{ Growth season } & \multirow[b]{2}{*}{ Treatments } & \multicolumn{4}{|c|}{ Yield and some vegetative growth traits } \\
\hline & & $\begin{array}{l}\text { Early fruit } \\
\text { yield } \\
\text { (Mg/fed.) }\end{array}$ & $\begin{array}{l}\text { Mean fruit Yield } \\
\text { (Mg/fed.) }\end{array}$ & $\begin{array}{c}\text { Fruit number } \\
\text { per plant }\end{array}$ & $\begin{array}{l}\text { Mean fruit } \\
\text { weight }(g)\end{array}$ \\
\hline \multirow{4}{*}{$1^{\text {st }}$} & $A_{E T o}$ & $1.35 \mathrm{a}$ & $12.0 \mathrm{a}$ & $9.65 a$ & $107 a$ \\
\hline & $\mathrm{B}_{\mathrm{Ep}}$ & $1.17 \mathrm{~b}$ & $10.0 \mathrm{~b}$ & $8.84 b$ & $95 c$ \\
\hline & $C_{P w}$ & $0.86 \mathrm{c}$ & $9.25 \mathrm{c}$ & $7.85 \mathrm{c}$ & $83 d$ \\
\hline & $D_{P_{C}}$ & $1.28 \mathrm{~b}$ & $10.62 b$ & $8.92 d$ & $98 \mathrm{~b}$ \\
\hline Significance L. & & $* * *$ & $* * *$ & $* * *$ & $* * *$ \\
\hline \multirow{4}{*}{$2^{\text {ed }}$} & $A_{\text {ETO }}$ & $1.42 \mathrm{a}$ & $12.13 a$ & $9.85 a$ & $108 a$ \\
\hline & $\mathrm{B}_{\mathrm{Ep}}$ & $1.22 \mathrm{~b}$ & $10.39 c$ & $9.10 \mathrm{~b}$ & $96 c$ \\
\hline & $\mathrm{C}_{\mathrm{PW}}$ & $0.90 \mathrm{c}$ & $9.14 d$ & $7.65 \mathrm{c}$ & $88 d$ \\
\hline & $D_{P_{C}}$ & $1.26 \mathrm{~b}$ & $10.94 b$ & $8.95 d$ & $101 \mathrm{~b}$ \\
\hline Significance L. & & $* * *$ & $* * *$ & $* * *$ & $* *$ \\
\hline
\end{tabular}

-Means within each column followed by the same letter/s are insignificant at 0.05 level of probability.

-*: significance at the 0.05 probability level, $* *$ : significance at the 0.01 probability level, and $* * *$ : significance at the 0.001 probability level. 


\section{Early and mean fruit yield (Mg/fed.):}

Yield of the first five harvests were considered as early yield. Obtained data showed highly significant effect of the different irrigation regimes on the early and mean squash fruit yield. There was a significant positive linear correlation between the yield (Mg/fed.) and applied irrigation water $\left(I_{r}\right)$ as well as water consumption $\left(E_{t}\right)$ as presented in Fig. (2). A $A_{\mathrm{ETO}}$ treatment had the maximum early and mean fruit yield of $1.42,1.35$ and $12.13,12.0 \mathrm{Mg} /$ fed. for the first and second growing seasons, respectively. Slightly decrease in early and mean fruit yield was noticed by $D_{P C}$ and $B_{E P}$ treatments as illustrated in Table (6). These results confirmed that irrigation scheduling based on the $A_{E T O}, D_{P C}$ and $B_{E P}$ treatments encouraged plant establishment and enhanced the early flowering process. On the other hand, $\mathrm{C}_{\mathrm{PW}}$ treatment, in which irrigated with water amount based on the percentage of wetted area $\left(P_{w}\right)$ produced the lowest early and mean yield of $0.86,0.90$ and $9.25,9.14 \mathrm{Mg} / \mathrm{fed}$. for the first and second growing season, respectively. This might be due to using a constant $\mathrm{P}_{\mathrm{w}}$ value of $46 \%$ throughout the growing season, which was quit high for the early growth period and quit low for late growth stages. It could be concluded that insufficiency or excessive water during the early growth period inhibited the plant development and decreased the squash yield. On the other hand, irrigation scheduling method based on the percentage of canopy cover appeared to be reasonable and effective one in terms of early and mean squash fruit yield compared with the constant percentage of wetted area throughout the growing season. This is in agreement with the results obtained by Oner and Dernet (2008) and Amer (2011).

2013

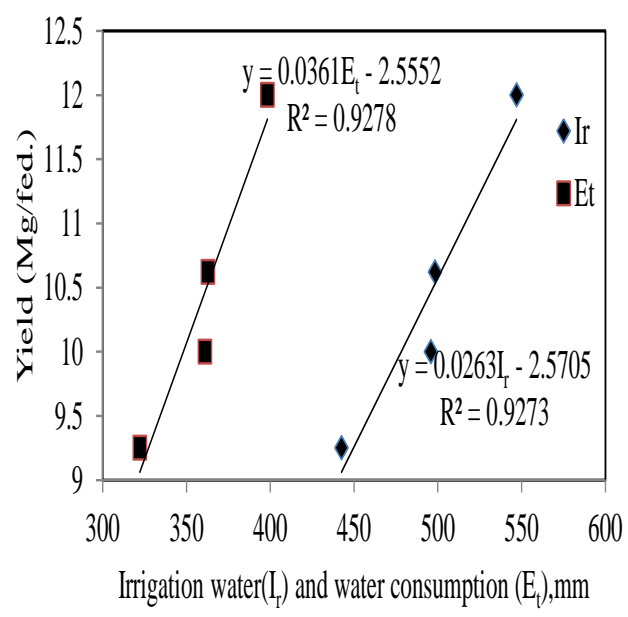

2014

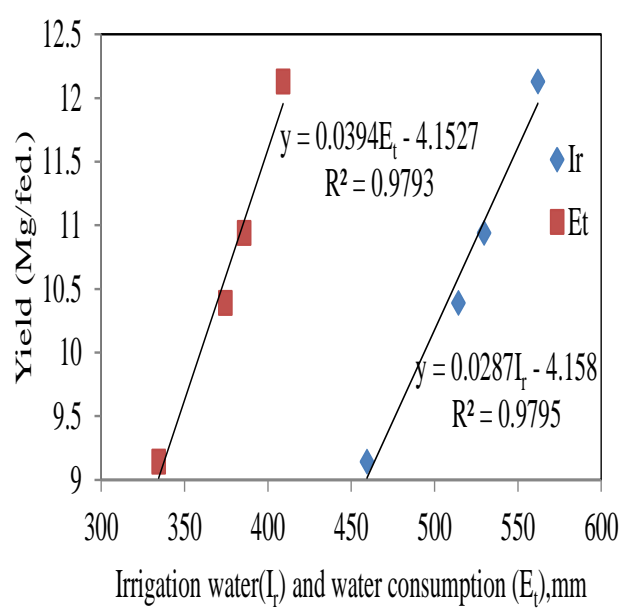

Fig. 2. Irrigation water, water consumption and squash yield relationships

\section{Fruits number per plant:}

Fruit number data of the different irrigation scheduling treatments are presented in Table (6). There was a significant increase in fruit number per plant as $I_{r}$ and $E_{t}$ increased. $A_{\text {Eто }}$ treatment had the highest fruit number per plant of 9.85 and 
9.65 for thesecondand first growing seasons, respectively. $D_{P C}$ and $B_{E P}$ treatments ranked the second and had the same statistical group as shown in Table. (6) while, $\mathrm{C}_{\mathrm{PW}}$ treatment had the minimum fruit number per plant of 7.85 for both two growing seasons. These results confirmed that proper irrigation scheduling resulted in increasing the fruit number per plant and consequentlyincreasing the fruit yield.

\section{Mean fruit weight and fruit weight per plant $(g)$ :}

There was a highly significant effect of the different irrigation scheduling regimes onmean fruit weight and fruit weight per plant as illustrated in Tables ( 6 and 7). For given irrigation scheduling strategy, mean fruit weight and fruit weight per plant were higher when adequate irrigation was applied. The maximum mean fruit weight and fruit weight per plant of 108 and $945 \mathrm{~g} ; 107$ and $935 \mathrm{~g}$ were obtained by $A_{\text {ETO }}$ treatmentfor thesecondand first growing seasons, respectively and followed by $D_{P C}$ and $B_{E P}$ treatments. However, there was no significant difference between $D_{P C}$ and $B_{E P}$ treatments in the second growing season in terms offruit weight per plant. Superior irrigation in early growth stage or insufficiency water in late growth stages as demonstrated by $C_{P W}$ treatment decreased the fruit weight, fruit weightper plantand consequently the yield as declared in Tables ( 6 and 7).

Table 7. Fruit weight per plant, mean fruit length, mean fruit diameter and IWUE as affected by different irrigation scheduling strategies.

\begin{tabular}{|c|c|c|c|c|c|}
\hline \multirow[b]{2}{*}{ Growth season } & \multirow[b]{2}{*}{ Treatments } & \multicolumn{3}{|c|}{ Some vegetative growth traits and IWUE } & \multirow[b]{2}{*}{$\begin{array}{l}\text { IWUE } \\
\mathrm{Kg} / \mathrm{m}^{3}\end{array}$} \\
\hline & & $\begin{array}{c}\text { Fruit weight } \\
\text { per plant } \\
(\mathrm{g}) \\
\end{array}$ & $\begin{array}{c}\text { Mean } \\
\text { Fruit length } \\
(\mathrm{mm}) \\
\end{array}$ & $\begin{array}{c}\text { Mean } \\
\text { Fruit diameter } \\
(\mathrm{mm}) \\
\end{array}$ & \\
\hline \multirow{4}{*}{$1^{\text {st }}$} & $A_{E T O}$ & $935 a$ & $162 a$ & $37.3 a$ & $5.22 a$ \\
\hline & $\mathrm{B}_{\mathrm{Ep}}$ & $815 c$ & $150 \mathrm{~b}$ & $33.7 \mathrm{~b}$ & $4.80 \mathrm{~b}$ \\
\hline & $\mathrm{C}_{\mathrm{Pw}}$ & $623 d$ & $134.3 c$ & $29.3 c$ & $4.98 \mathrm{ab}$ \\
\hline & $D_{P c}$ & $870 \mathrm{~b}$ & $149.6 \mathrm{~b}$ & $35 d$ & $5.07 a b$ \\
\hline Significance L. & & $* * *$ & $* *$ & $* * *$ & $*$ \\
\hline \multirow{4}{*}{$2^{\text {ed }}$} & $A_{\text {ETO }}$ & $945 a$ & $167 a$ & $37.5 a$ & $5.13 a$ \\
\hline & $\mathrm{B}_{\mathrm{Ep}}$ & $830 \mathrm{~b}$ & $151.7 \mathrm{~b}$ & $33.7 \mathrm{~b}$ & $4.81 \mathrm{~b}$ \\
\hline & $\mathrm{C}_{\mathrm{PW}}$ & $630 c$ & $136.7 \mathrm{c}$ & $29.7 c$ & $4.74 b$ \\
\hline & $D_{P C}$ & $855 b$ & $151.3 \mathrm{~b}$ & $34.9 \mathrm{bd}$ & $4.92 a$ \\
\hline Significance L. & & $* * *$ & $* *$ & $* * *$ & $*$ \\
\hline
\end{tabular}

-Means within each column followed by the same letter/s are insignificant at 0.05 level of probability.

$-*$ : significance at the 0.05 probability level, $* *$ : significance at the 0.01 probability level, and $* * *$ : significance at the 0.001 probability level. 


\section{Mean fruit length and diameter $(\mathrm{mm})$ :}

Fruit length and diameter are the most factors affecting the yield, treatments with higher fruits length and diameter produced higher yield. Obtained data showed linear increase in squash yield as the mean fruit length and diameter increased as presented in Fig. (3) and Table (7). Also, different Irrigation scheduling regimes showed significantly effect on fruit length and diameter among the treatments, fruit length and diameter increased as the $I_{r}$ and $E_{t}$ increased as shown in Fig. (4). $A_{\text {Eто }}$ treatment had the maximum fruit length of 167 and $162 \mathrm{~mm}$ and fruit diameter of 37.5 and $37.3 \mathrm{~mm}$ for thesecondand first growing seasons, respectively. No significant differences among
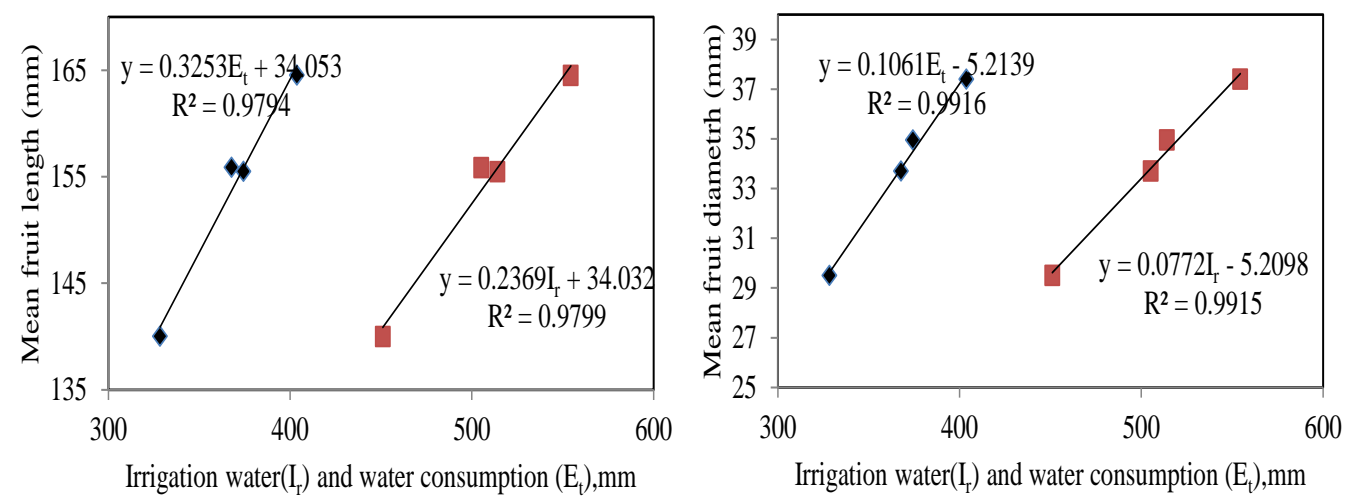

Fig 3. The relationship between mean fruit length, diameter and irrigation water.

$D_{P C}$ and $B_{E P}$ treatments in terms of mean fruit length were occurred. $C_{P W}$ treatment had the minimum fruit length of 139.3 and $141.7 \mathrm{~mm}$ and minimum mean fruit diameter of 29.3 and $29.7 \mathrm{~mm}$ for the first and second growing seasons respectively. These results were in accordance with those of Ozbahce and Tari (2010), who mentioned that fruit weight, length and diameter significantly affected by irrigation quantity under trickle irrigation.
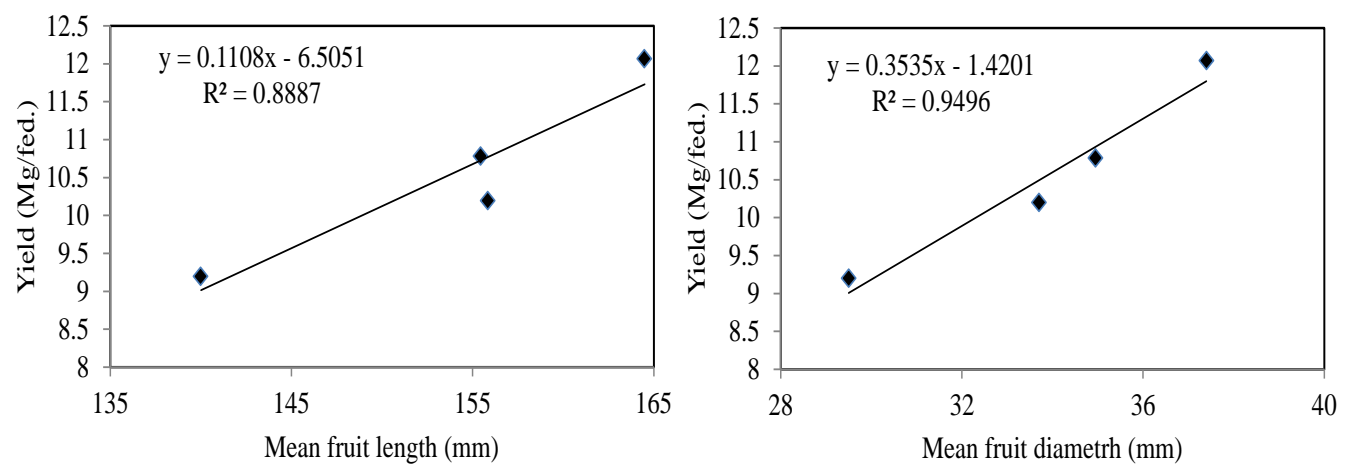

Fig. 4. The relationship between mean fruit length, diameter $(\mathrm{mm})$ and the yield (Mg/fed.) 


\section{Irrigation water use efficiency (IWUE):}

IWUE values varied significantly among the treatments depending on the different treatments and experimental years as shown in Tab.(7). A $_{\text {ETO }}$ treatment had the maximumIWUE values of 5.22 and $5.13 \mathrm{~kg} / \mathrm{m}^{3}$ for the first and second growing season, respectively followed by $D_{\mathrm{PC}}$ treatment which had satisfactory IWUE values of 5.07 and $4.92 \mathrm{~kg} / \mathrm{m}^{3}$ for the first and second growing season, respectively. $B_{E P}$ treatment had the lowest IWUE value of $4.80 \mathrm{~kg} / \mathrm{m}^{3}$ for the first season, while $C_{P W}$ treatment recorded the lowest IWUE value of $4.74 \mathrm{~kg} / \mathrm{m}^{3}$ for the second season. These results demonstrated that plants which irrigated with proper amount of irrigation water in early growth stages grow better and their photosynthetic efficiency increased. Meanwhile, excessive water in early growth stages led to flowers shedding,yield decreasing and consequently inefficient use of irrigation water. These results were in harmony with those obtained by Zotarelli et al. (2008).

\section{CONCLUSION}

The two- year's field study provided substantial information's for assessing the usefulness of using irrigation scheduling based on the percentage of canopy cover and wetted area. From the obtained results, it could be concluded that:

-Appropriate use of irrigation scheduling strategies can allow farmers to sustain profitable yield while it can greatly improve the water use efficiency which is a measure of the productivity of water used by the crops. Consequently, in regions having similar environmental conditions irrigation scheduling based on the percentages of the canopy cover should be taken into consideration, where they are related directly to the site- specific, field configuration and plant vigor.

-Irrigation scheduling based on the percentage of the canopy cover could be used as an alternative to using crop coefficient $\left(K_{c}\right)$ valuesespecially, when $k_{c}$ values not availableor not correctly defined.

-Irrigation scheduling based on the percentage of wetted area $\left(P_{w}\right)$ seems to be not realistic or sensible, because using a fixed $P_{w}$ value is not appropriate for all plant growth stages. 


\section{REFERENCES}

1. Abou Zeid, K., 2002. Egypt and the world water Goals. Egypt statement in the world summit for sustainable development and beyond, Johannesburg.

2. Allen, R.G.,L.S. Pereira, D. rase and M. Smith, 1998. Crop evapotranspiration guide lines for computing crop water requirements. FAO irrigation and drainage paper, 56 Rome.

3. Amer, K. H., 2011. Effect of irrigation method and quantity on squash yield and quality. Misr J. Ag. Eng., 28 (1):87-111.

4. Black, J. D. F., 1971. The basis of trickle irrigation. Trickle irrigation Australia Booklet published by ICI, Australia.

5. Cetin, O. and L. Bilgel, 2002. Effects of different irrigation methods on shedding and yield of cotton. Agric. Water Manage. 54(1): 1-15.

6. CoHort Software,1986. Costat 6.0 P.O. Box 1149, Berkeley, C A 94701, USA.

7. Doorenbos, J. and W.O. Pruit, 1977. Guidelines for predicting Crop water Requirements, FAO irrigation and drainage paper,24 Rome, Italy.

8. El- Gindy, A. M., E. S. El- Banna, M. El-Adl, and M. F. Metwalley, 2009. Effect of fertilization and irrigation water levels on summer squash yield under drip irrigation .Misr J. Eng., 26(1):94-106.

9. Elliades, G., 1988. Irrigation of greenhouse grown cucumber.J. of Hort. Sci. 63 (2).235-239.

10. EL-Raey, M., 1999.Impact of climate change of Egypt, special report, EEMN, Egypt.

11. Gavilan, P. and F. Castillo-Llanque, 2009.Estimation reference evapotranspiration with atmometers in a semiarid environment. Agric. Water manage. 96 (2009) 465-472.

12. Hartz, T. K., 1993. Drip irrigation scheduling for fresh -market tomato production. Hortscience 28: 35-37.

13. Howell, T. A., 2006. Challenges in increasing water use efficiency in irrigated agriculture. The proceedings of the international symposium on water and land management for sustainable irrigated agriculture.April 4-8, 2006, Adana, Turkey.

14. Keller, J. and R.D. Bliesner, 1990.Sprinkler and Trickle Irrigation.Chapman and Hall, 115 fifth Avenue, New York, NY 10003. USA. P. 652.

15. Mario, H.,M. Bill,S. Jason and S. John, 1977. Western Oregon Squash Irrigation,Oregon state university Guide, Vol. 541, Department of Bio- resource Engineering.116Gilmore Hall, Corvallis. 
16. Norwood, C.A. and T.J. Dumler, 2002. Transition to dray land agriculture: Limited irrigation Va. Dry land corn. Agron. J. 94: 310-320.

17. Oner C. and D. Uygan, 2008. The effect of drip line spacing, irrigation regimes and planting geometries of tomato on yield, irrigation water use efficiency and net return.Agric. water manage. (95):949-958.

18. Ozbahce, A. and A. F. Tari, 2010. Effects of different emitter space and water stress on yield and quality of processing tomato under semi -arid climate conditions. Agric. water manage. (97):1405-1410.

19. Phene, C.J., R.L. McCormick,J. M. Miyamoto, D.W. Meek and K.R. Davis, 1985.Evapotranspiration and crop coefficient of trickle irrigation tomatoes.In proceeding of the Third International Drip /trickle irrigation Congress, Fresno, California, P.823-831.

20. Richard, M., A. Jose, G. Mark, and M. Keith, 2002.Spring squash production in California. Vegetable Research and information center, Vegetable Reproduction Series, California, Publication 7245.

21. Sanchez, P.,M. S. Swaminathan, P. Dobie, and N.Yuksel, 2005. Halving Hunger; it can be done, UN Millennium Project, UNDP.

22. Smith, M.,R. Allen, and L. Pereira, 1996.Proceeding of the International Conference of Evapotranspiration and Irrigation Scheduling.American Society of Agricultural Engineers, 3-6 November. Texas, USA.

23. Stanhill, G., 2002. Is the class A evaporation pan still the most practical and accurate metrological method for determining irrigation water requirements Agric. for Meteorol.112: 233-236.

24. Zotarelli, L.,m. D. Dukes, J. M. Scholberg, T. Hanselman, K. Le Femminella and R. Munozcarpen, 2008. Nitrogen and water use efficiency of zucchini squash for plastic mulch and bed system on a sandy soil. Sciatica Horticulture 116: 8-16. 


\title{
تأثير نظ مختلفة لجدولة عملية الري علي الإنتاجية والإستهلاك المائي لمحصول الكوسه تحت الظروف الحقلية
}

\author{
عبد الحليم محمد زيتون \\ معهُ بحوث الهندسة الزراعية - مركز البحوث الزراعية - الدقي - الجيزة- مصر
}

يهدف هذا البحث الي دراسة نأثثير سياسات مختلفة لجدولة عملية الري علي الإنتاجية والإستهلاك المائي لمحصول الكوسه تحت الظروف الحقلية. لتحقيق هذا الهدف اجريت تجارب حقليه خلالربيع

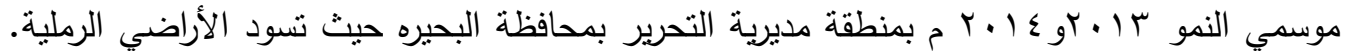
صمدت التجارب بإستخدام المربعات الكاملة العشوائيه في ثلاث مكرارات و التي إنتملت علي أربع طرق مختلفة لجدولة عملية الري تحت نظام الري بالتتقيط وهي: أ- جدولة عملية الري علي أساس تقدير البخر نتح القياسي (AETO) .

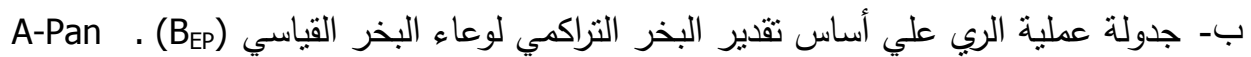

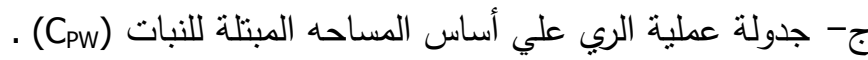

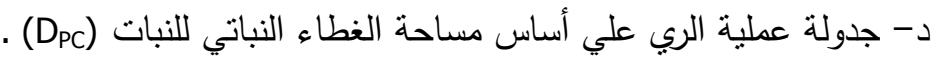
هذا ويمكن تلخيص أهم النتائج المتحصل عليها فيما يلي:

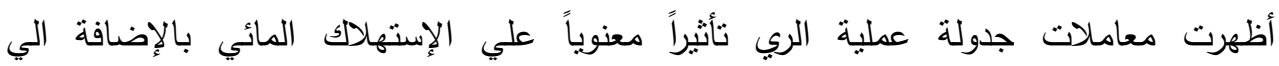
الإنتاجيةوصفات النمو و خصائص الجودة و كفاءة إستخدام المياه لمحصول الكوسة حيث:

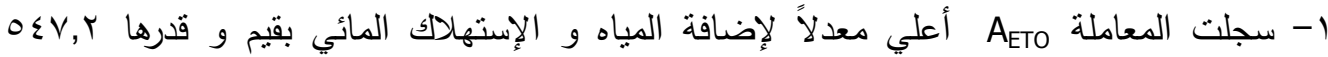

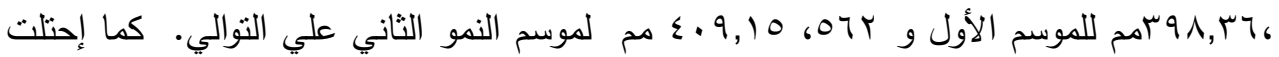

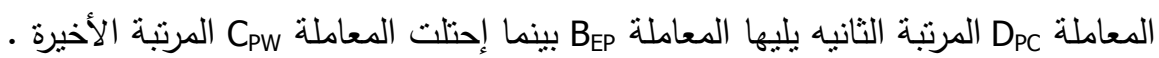

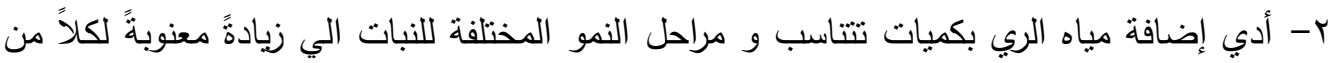

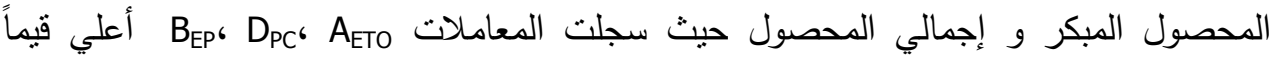

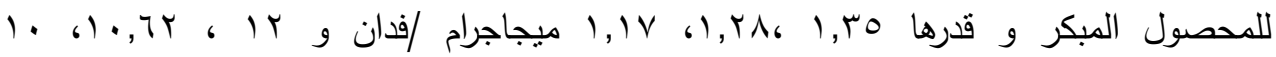
ميجاجرام/فدان كمتوسط إنتاجية للموسم الأول علي التوالي.هذا و لقد أظهرت النتائج للعام الثاني نفس الاتجاة لكلاً من المحصول المبكر و منوسط الإنتاجيه للفدان. ץ- أظهرت نتائج خصائص النمو و الجودة لمحصول الكوسة نوافقاً مع نتائج الإنتاجية و الإستهلاك المائي حيث أظهرت المعاملات BEP، DPC A A أفضل خصائص للنمو و جودة المحصول منمثلةً في عدد الثمارو متوسط و زن الثمرة للنبات ،الوزن المتوسط للثمرة بالإضافة الي متوسط طول و ولمان قطر الثرة. ع- سجلت المعاملة CPW أقل معدلات للإستهلاك المائي و معدلات إضافة المياه و كذلك خصائص النمو و الجودة والإنتاجية لمحصول الكوسة و الذي قد نرجعه الي عدم تتاسب كميات المياه 
المضافة للنبات و إحتباجاتة و فقاً لمراحل نموه المختلفة خاصةً مراحل النمو المبكرة مما كان له

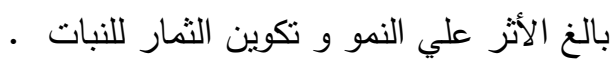

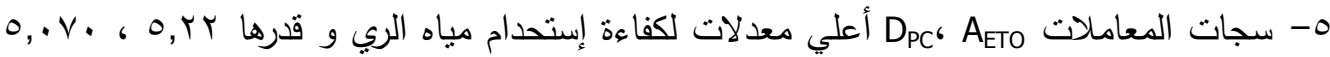

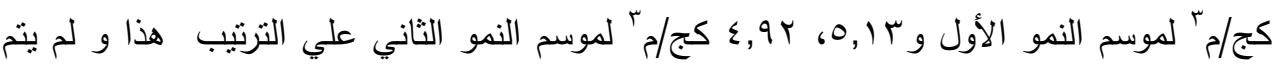

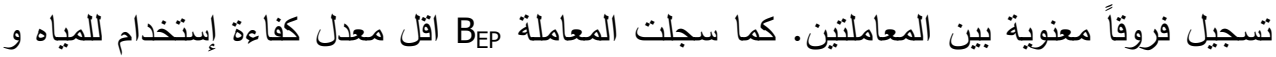

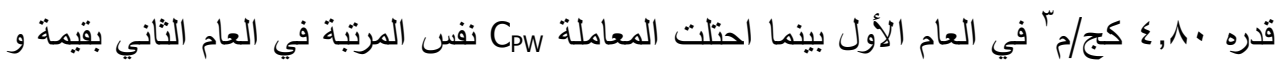

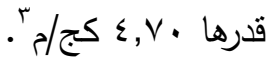
هذا و لقد خلصت الدراسة الي: - الي: 1- الاسلوب الأمتل لجدولة مياه الري هو الذي يكفل إضافة كميات مياه تنتاسب و الإحتياجات المائية وفقاً لمراحل النمو المختلفة للنبات. r- إمكانية استخدام أسلوب نسبة الغطاء النباتي لجدولة عملية الري كبديل لمعامل المحصول نظراً لإستخدام قيماً لنسب الغطاء النباتي تنتاسب و مراحل نطور النمو للنبات مما يفي بإحتباجاته المائية دون نعرضه للإجهاد المائي أو الإسراف في كميات المياه المضافة خاصةً في مراحل

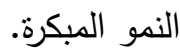
r- لم يحقق اسلوب جدولة عملية الري علي أساس المساحة المبتلة نتائجاً مرضية و قد يرجع هذا الي إستخدام قيمةً ثابتة للمساحة المبتله خلال موسم النمو مما لاينوافق و إحتباجات النبات المائية وفقاً

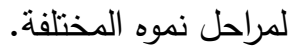

